\title{
Catatan Editorial \\ Edisi Khusus tentang Covid-19, New Normal, dan Perencanaan Pembangunan
}

\author{
Oleh: Muhyiddin dan Hanan Nugroho
}

Pembaca setia Jurnal Perencanaan Pembangunan yang saya hormati,

Pada edisi ini, IJDP mengetengahkan topik tentang Covid-19 dan Perencanaan Pembangunan dalam berbagai bidang dan sektor pembangunan. Artikel-artikel yang disajikan mengulas berbagai masalah pandemi Covid-19 yang kemudian berdampak pada perekonomian dan pada bidang-bidang yang lain. Dampak pandemi Covid-19 terhadap berbagai sektor ekonomi tentunya berbeda kedalamannya, namun tidak bisa dipungkiri bahwa sebagian besar berdampak negatif.

Mohamad Ikhsan Modjo mengawali dengan tulisannya yang mengulas kondisi makroekonomi Indonesia yang berjudul "Memetakan Jalan Penguatan Ekonomi Pasca Pandemi Pandemi Covid-19". Pandemi Covid-19 telah menyebabkan menurunnya perekonomian dan aktivitas di berbagai sektor dan wilayah di Indonesia. Walau economic shock yang disebabkan oleh pandemi Covid-19 berangsur mereda seiring stabilnya pasar keuangan domestik dan menggeliatnya beberapa sektor perekonomian. Akan tetapi mengingat sifatnya yang memukul baik sisi penawaran mau pun permintaan dari perekonomian, upaya pemulihan masih memerlukan lebih banyak waktu. Pada saat yang sama, penyebaran virus juga belum menunjukkan tanda-tanda berakhir seiring dengan masih meningkatnya tren kasus dan kematian terkonfirmasi. Di satu sisi, tuntutan untuk memulai kembali berbagai aktivitas sosial dan ekonomi semakin menguat ditandai dengan dilonggarkannya pembatasan sosial di banyak daerah. Di sisi lain, infrastruktur kesehatan publik yang ada masih belum memadai. Sehingga terdapat risiko yang tinggi untuk menggerakkan kembali berbagai roda aktivitas sosial dan ekonomi secara normal.

Hanan Nugroho menyambungnya dengan makalah "Pandemi Covid-19: Tinjau Ulang Kebijakan Mengenai PETI (Pertambangan Tanpa Izin) di Indonesia” yang mengangkat permasalahan yang dihadapi kegiatan pertambangan rakyat skala kecil yang selama ini digolongkan sebagai PETI (pertambangan tanpa izin). Di balik reputasi sebagai negara produsen dan pengekspor bahan-bahan tambang terkemuka, jutaan rakyat Indonesia hidup sebagai penambang tradisional yang rentan terhadap aspek kesehatan, ekonomi, sosial, hukum, dan lingkungan. Nugroho mengusulkan agar Indonesia mengubah cara pandang terhadap pertambangan rakyat skala kecil, mewadahinya secara hukum, memberikan bantuan teknik, akses finansial dan pasar, sehingga memberikan nilai ekonomi dan manfaat sosial yang lebih baik, serta mengurangi kerusakan lingkungan dari kegiatan tersebut.

Di balik musibah, pandemi Covid-19 ternyata juga menjanjikan kesempatan perubahan. Oswar Mungkasa menulis makalah dengan judul "Bekerja dari Rumah (Working from Home/WFH) : Menuju Tatanan Baru Era Pandemi COVID-19” yang mengulas bagaimana bekerja dari rumah, belajar di rumah yang secara ekonomi-energi lebih efisien dan telah diimajinasikan dari dulu sekarang seolah mendapat kesempatan untuk melakukan prakteknya. Sebetulnya teknologi untuk 'bekerja dari rumah' itu telah siap dari dulu, namun masyarakat yang terikat pada pola business as usual terus mengabaikan peluang pemanfaatannya. Covid-19 membantu penerapannya. Demikian pula, berbagai keahlian teknologi informasi dan komunikasi sekarang dikuasai lebih cepat oleh para pekerja yang harus bekerja dari rumahnya, sementara sebelumnya mereka mengandalkan pada spesialist di kantor. 
Haryanto melakukan riset kuantitatif untuk menunjukkan dampak Covid-19 terhadap ekonomi Indonesia. Hasilnya disajikan dalam makalah "Dampak Covid-19 terhadap Pergerakan Nilai Tukar Rupiah dan Indeks Harga Saham Gabungan (IHSG)”. Namun, tidak berhenti pada model kuantitatif hubungan Covid-19 dengan nilai tukar Rupiah/US\$ dan IHSG, Haryanto juga mengusulkan sejumlah rekomendasi untuk memitigasi dampak Covid19, terutama yang berkenaan dengan peran pemerintah dan masyarakat.

Nur Laila Widyastuti dan Hanan Nugroho menganalisis dampak Covid-19 terhadap industri minyak dan gas bumi, industri yang penting dalam ekonomi Indonesia. Dalam makalah mereka, "Dampak Covid-19 terhadap industri minyak \& gas bumi dan rekomendasi kebijakan untuk Indonesia" mereka menyatakan bahwa dampak itu adalah penurunan konsumsi BBM, penurunan harga minyak dan gas bumi, serta penurunan produksi migas (yang namun tetap berdampak kelebihan produksi karena konsumsi anjlok). Dampak di industri hulu termasuk penghentian produksi hingga penutupan perusahaan eksplorasi dan eksploitasi migas, sementara di sisi hilir, kegiatan pengilangan banyak yang dikurangi. Agak kontroversial bahwa mereka mengusulkan agar, sebagai dampak dari Covid-19, harga BBM di Indonesia tidak perlu diturunkan. Sejumlah rekomendasi juga dikemukakan, misalnya tentang pentingnya membangun strategic oil reserves di Indonesia.

Suprayoga Hadi mengetengahkan makalah "Pengurangan Risiko Pandemik Covid-19 Secara Partisipatif: Suatu Tinjauan Ketahanan Nasional terhadap Bencana”. Indonesia sesunggguhnya adalah negeri yang akrab dengan bencana, baik bencana alam (tsunami, gempa, dsb.), ekonomi (krisis moneter 1998), iklim (banjir, kebakaran hutan, dsb.), konflik sosial dan keamanan, dsb. Penulis makalah menggunakan kerangka ketahanan nasional terhadap bencana untuk melihat kasus pandemi Covid-19 di Indonesia. Rekomendasinya adalah agar mengupayakan perbaikan dalam kerangka kebijakan terkait regulasi, kelembagaan, dan pembiayaan, yang diarahkan untuk meningkatkan hasilguna dan dayaguna pencegahan dan pengurangan risiko bencana Covid-19 secara partisipatif, dengan mengoptimalkan peran masyakarat lokal.

I Dewa Gde Sugihamretha menulis makalah "Respon Kebijakan: Mitigasi Dampak Wabah Covid-19 Pada Sektor Pariwisata" dimana mengulas dampak Covid-19 pada salah satu sektor yang terpukul paling parah, yaitu pariwisata. Sektor yang tengah digadanggadang untuk menjadi penyumbang terbesar ekonomi tanah air. Dalam makalahnya, Sugihamretha memperlihatkan bagaimana respon kebijakan yang dilakukan oleh berbagai negara di dunia terhadap sektor pariwisata sehubungan dengan pandemi Covid-19. Penulis makalah kemudian mengusulkan kebijakan serupa untuk Indonesia, dengan menekankan pentingnya kerja sama antar stakeholders dan pendekatan intersektoral.

Apakah pandemi Covid-19 berdampak pada penyediaan air minum di Indonesia? Ini diulas oleh Eko Wiji Purwanto dalam makalahnya "Pembangunan Akses Air Bersih Pasca Krisis Covid-19". Secara spesifik hal itu belum nyata terlihat. Pandemi ini mengingatkan bahwa rumah tangga yang terlayani air minum sehat di Indonesia masih sangat kecil, dan perjalanan untuk memenuhi akses universal air minum aman tahun 2030 (sesuai target Tujuan Pembangunan Berkelanjutan) masih sangat jauh. Perlu mempercepat pembangunan air minum/bersih segera setelah pandemi Covid-19 berakhir. Pembangunan air bersih membutuhkan leadership yang mumpuni dengan otoritas tinggi.

Irfan, Januarita Dyah Pitaloka, dan Adif Rachmat Nugraha mengangkat permasalahan ASN tenaga kesehatan dengan judul "Rekrutmen ASN Tenaga Kesehatan untuk merespon Covid-19". Ketika Covid-19 melanda, makin terungkap bahwa sumber daya manusia ASN (Aparatur Sipil Negara) ternyata tidak seimbang antara kebutuhan dengan tenaga kerja yang ada, khususnya di pemerintahan dan di sektor kesehatan. Tenaga kesehatan untuk merespon pandemi Covid-19 sangat terbatas, demikian pula tenaga 
kesehatan lainnya seperti dokter. Mismatch ini, dalam skala yang lebih luas, memerlukan beberapa kebijakan yang berhubungan dengan reformasi birokrasi, termasuk menyangkut jabatan struktural dan fungsional.

Makalah "Kajian Kebijakan dan Arah Riset Pasca-Covid-19” yang ditulis Dharendra Wardhana berupaya mengidentifikasi ruang dan potensi kajian yang relevan dengan penanganan dan kebijakan pasca Covid-19 dalam berbagai disiplin dan perspektif. Penulis makalah menyatakan bahwa celah riset masih terbuka lebar dan mengundang para periset untuk segera berkontribusi menyampaikan gagasan ilmiah beserta solusi konstruktif, yang bersifat lintas sektoral, multidisiplin.

Muhyiddin mengetengahkan bagaimana respon kebijakan perencanaan pembangunan di masa pandemi Covid-19 dengan makalah berjudul "Covid-19, New Normal, dan Perencanaan Pembangunan di Indonesia”. RPJMN 2020 - 2024 telah disahkan sebelum Covid-19 menyerang Indonesia. Lalu, ketika melanda Indonesia, segala perencanaan jangka pendek tahun 2020 harus dimodifikasi sedemikian rupa. Bagaimana Pemerintah meresponnya dalam jangka menengah? Muhyiddin mencoba mengulas tantangan berat Pemerintah Indonesia dalam mengevaluasi secara ex ante RPJMN 2020 - 2024. Apakah tetap dengan rencana semula dengan asumsi normal, merevisi sebagian, atau menyusun ulang dengan penyesuaian asumsi, situasi, dan kondisi akibat pandemi Covid-19 ini.

Langitpun semakin biru! Lingkungan semakin bersih karena terbebas dari polusi dan kemacetan lalu lintas yang berkurang drastis selama wabah terjadi. Dunia menikmati rehat sejenak dari eksploitasi penghuninya. Mungkin sebagian target-target pembangunan perubahan iklim dapat tercapai tanpa perlu mengeluarkan upaya dan biaya yang besar dalam masa pandemi Covid-19 ini. Dibuktikan misalnya di industri pembangkitan listrik yang memensiunkan sebagian PLTU (pusat listrik tenaga uap) Batubara yang selama ini membakar bahan bakar fosil dan melepaskan emisi karbondioksidanya ke udara.

Pandemi Covid-19 akan memperlambat roda perekonomian, namun tanpa upaya sigap dari pemangku kebijakan untuk selamatkan nyawa penduduk Indonesia, maka optimisme perekonomian tidak akan pernah datang. Optimisme dan sentimen positif ekonomi baru akan terjadi jika pandemi Covid-19 dapat diatasi, setidaknya menunjukkan tanda-tanda terkendali dan akhirnya dapat diselesaikan. Upaya Pembatasan Sosial Berskala Besar (PSBB) sangat penting dikedepankan, sebelum nanti vaksin Covid-19 akan ditemukan, atau kita terpaksa harus berdampingan dengan Covid-19 sebagai sebuah cara hidup di zaman normal baru.

Dalam zaman normal baru kegiatan ekonomi dapat dilakukan, namun dengan standar kesehatan serta fasilitas kerja dan infrastruktur publik yang memungkinkan manusia untuk hidup berdampingan dengan Covid-19 yang belum pergi. Kita harus siap dengan kemungkin perubahan ke arah itu. Pada dasarnya, kita pun sudah banyak melakukan perubahan agar dampak pandemi Covid-19 tidak terlalu besar memakan korban. Misalnya dengan melakukan realokasi anggaran pembangunan untuk keperluan program social safety net, dsb. Perubahan lebih besar masih harus kita tempuh.

Bagaimana dengan praktek perencanaan kita? Makin ke sini, fenomena VUCA (Volatility, Uncertainty, Complexity, and Ambiguity) makin sering terlihat, menggambarkan situasi dunia masa kini. Termasuk dengan hadirnya Covid-19 ke tengah cara hidup kita. Nampaknya perencanaan pun harus lebih adaptif dan mengakomodasi fenomena VUCA. Mungkin kita belum tahu persis bagaimana cara perencanaan di masa normal baru atau di masa depan itu akan dilakukan. Yang pasti pandemi Covid-19 semakin mengungkap titik lemah sistem kesehatan, dan banyak sistem lainnya di Tanah Air. Guncangan terhadap sistem kesehatan berpengaruh pada prioritas alokasi fiskal. Pengalihan perhatian ke sektor 
kesehatan berimplikasi pada penurunan prioritas pada sektor-sektor non-kesehatan, yang berdampak perubahan haluan pembangunan. Ke depan hal seperti ini akan sering terjadi.

Selamat membaca.

Muhyiddin \& Hanan Nugroho

Dewan Editor IJDP

The Indonesian Journal of Development Planning

Volume IV No. 2 - Juni 2020 